\title{
PRESENTACIÓN. UN NUEVO DESAFÍO
}

\author{
PRESENTATION. A NEW CHALLENGE
}

APRESENTAÇÃO. UN NOVO DESAFIO

\author{
Víctor Amar \\ Director de la revista Hachetetepé \\ Universidad de Cádiz, España \\ https://orcid.org/0000-0001-9036-2651
}

victor.amar@uca.es

Cómo citar este artículo: Amar, V. (2021). Presentación. Un nuevo desafío. .Hachetetepé.
Revista cientifica en Educación y Comunicación, (23),
https://doi.org/10.25267/Hachetetepe.2021.i23.2001

Un nuevo desafío; un nuevo número. Otra vez, nuevas ilusiones; otra vez, con la corresponsabilidad de un trabajo pensado en y para nuestros lectores. Una tradición que se renueva cada seis meses, tras otro dilatado tiempo de callado trabajo. El cual cuenta con una consecuencia: la parte invisible. Pero la que se muestra visible, no deja de ser un bonito pretexto para que el lector curse una invitación hacia la lectura y el disfrute de la revista Hachetetepé (http). Y son veintitrés las veces que hemos renovado esta bendita invitación a la lectura y al disfrute de nuestra revista. Pero siempre con la sensación de cómo será el resultado final en sus manos. Nosotros (y me refiero al equipo de todas las personas que componemos la revista http) ya le hemos visto la "cara". Pero siempre pensamos en los lectores y en la sensación que les podría causar el presente número. Tiene gracia, pues esta preocupación es compartida con otros tantos compañeros. No obstante, si la revista es un éxito, sin duda se lo merecen a todos ellos. Lo contrario, la responsabilidad es mía, del director de la misma. Y no lo digo como una estrategia de falsa modestia... Es pura convicción; es asumir mis responsabilidades que, insisto, se renuevan cada seis meses con este "pequeño" ejercicio literario. Que ojalá, alguna vez, adquiera la dimensión de subgénero. Pues les aseguro que hablar sobre lo que se hace en equipo, a raíz del trabajo de otros que, a su vez, ha sido evaluado por expertos externos al grupo... Puede llegar a resultar un desafío que, al menos yo, no termino de acostumbrarme.

Pues dicho, lo que quería decirles; ahora me centro en lo que tengo que presentarles.

Pues muy bien, ya está aquí. Lo tienen en sus pantallas, con la ilusión renovada de un trabajo bien hecho que aglutina a un sinnúmero de personas. El resultado es el siguiente: seis artículos y una reseña. Cada trabajo con sus singularidades aglutina, mejor me atrevería a decir que atesora, muchas horas de investigación y dedicación. Inclusive, diría que de voluntades por querer contribuir al desarrollo y el conocimiento de la educomucación. Y, ello, no es nada baladí.

Lo fácil sería entrar a destacar las virtudes de estos escritos. Lo habitual es hacerlo. Y no lo discuto. A veces, me resulta interesante cuando los leo en las otras revistas. Pero, me inclino por invitarles a la lectura en su conjunto. Cuando los leía (entre la obligación, el deseo y la necesidad) en todos veía algo interesante, relevante e, inclusive, que me 
dejaba con la voluntad de saber más. Es decir, considero que cumplía su misión: la de llamar y abrir la mente. Pues en efecto, las diferentes aportaciones en forma de artículos, les irán a dejar con el deseo de querer y seguir sabiendo. Y no hay nada más extraordinario en esto de la educación, o en la vida misma, que sentirse o estar motivado. ¡Cuidado! Pues se contagia... Y, en este sentido, el médico, erudito y humanista del quatrocento italiano Girolamo Fracastoro (1950) se adelantó a los hechos de la microbiología y la epidemiología.

Yo me contagié de y por ellos. Y no me arrepiento. Ahora estoy con la inquietud de contagiarles a ustedes; de lo cual tampoco me arrepentiría. Lean cada uno de los artículos y disfruten. Como sintomatología, tal vez, se queden sin palabras, tendrán avistamientos de una escuela libre de homofobia, mirarán a la vida y la verán con violencia cero, y de nuevo la historia les dará una lección o, de repente, recuperarán la necesidad de jugar (gamificación) y terminarán creyendo que la Covid ha sido un motor de transformación educativa.

Si es así, se sienten así o creen que pueden llegar a serlo. Les diría que consulten a su farmacéutico o mejor, continúen leyendo la revista http. Se les pasará con una pócima a modo de otro número de nuestra revista.

Y digo nuestra revista, pues incluyo a todos los miembros del equipo. De lo contrario, esto no tendría sentido y sería para nosotros una pesadilla que no se cura ni con el mejor de los remedios, médico o balneario.

Y hablando de virus, les adelanto que, en el próximo número 24 , tendremos un monográfico sobre "Tecnología, comunicación y educación en tiempos del post Covid". Veamos la luz al final del túnel. Empecemos a creernos que se está y se debe salir de este dolor tan inmenso que ha supuesto la pandemia.

Bueno. Aquí tienen un número más de la revista http.

Disfruten de su lectura. Y estas líneas son un pequeño tributo a toda la comunidad de la revista http; donde les incluyo...

\section{REFERENCIA BIBLIGRÁFICA}

Fracastoro, G. (1950). Il contagio, le malattie contagiose e la loro cura. Olschki. 